\title{
Synthesis and Reaction of 1,5,3,7-Diazadiphosphocine-1,5-Dicarboxylic Acids
}

\author{
Dai II Jung*, Seung Hwan Cho', Ju Hyun Song, Do Hun Lee, Yong Gyun Lee, Yu Mi Park, \\ Soon Kyu Choi ${ }^{\dagger}$ and Jung Tai Hahn ${ }^{2}$
}

Department of Chemistry Dong-A University Busan 604714 Korea,

${ }^{1}$ Han-mi Pharmaceutical Institute, ${ }^{2}$ Department of Beautycare, Youngdong University, youngdong 370-701, Korea

Received June 21, 2007 / Accepted July 12, 2007

\begin{abstract}
In order to synthesize new bioactive compounds and contrasting agents, reactions of glycine and glutamic acid as an animo acid with paraformaldehyde and hypophosphorous acid were executed. Products are 3,7-dihydroxy-3,7-dioxoperhydro-1,5,3,7-diazadiphosphocine-1,5-diacetic acid 1 and 3,7-dihydroxy3,7-dioxoperhydro-1,5,3,7-diazadiphosphocine-1,5-di-(2-glutaric acid) 3. 2-[5-(1,2-Dicarboxyethyl)-3,7-dihydroxy-3,7-dioxo-315.715-[1,5,3,7] diazadiphosphocan-1-yl]-succinic acid 2 by using aspartic acid was not obtained. Esterification of 3,7-dihydroxy-3,7-dioxoperhydro-1,5,3,7-diaza-diphosphocine-1,5-diacetic acid 1 by treatment of methanol, ethanol, and propanol were executed. 3,7-Dihydroxy-3,7-dioxoperhydro-1,5,3,7-diazadiphosphocine-1,5-diacetic acid methyl ester 4, 3.7-dihydroxy-3,7-dioxoperhydro-1,5,3, 7-diazadiphosphocine-1.5-diacetic acid ethyl ester 5, and 3,7-dihydroxy-3,7-dioxoperhydro-1,5,3,7-diazadiphosphocine-1,5-diacetic acid propyl ester 6 were respectively synthesized in good yields. Continuously, we will try synthesis of novel compounds and evaluation of biological activity.
\end{abstract} Key words - Contrasting agent, esterfication, amino acid, 1,5,3,7-diazadiphosphocine-1,5-dicarboxylic
acid

\section{Introduction}

In the last few years, great efforts have been devoted to the development of efficient ligands for transition metal ions, in order to obtain complexes whose stability, physical properties and biodi- stribution could make them suitable for application as contrast agents for magnetic resonance imaging (MRI), diagnostic therapeutic radiopharmaceuticals or fluorescent bioassays $[2,4,5,10,12]$.

Most of these ligands belong to the huge class of polyaminopolycarboxylic acids as diethylenetriaminopentaacetic acid (DTPA), 1,4,7,10-tetraazacyclododecane-1,4,7,10-tetraacetic acid (DOTA) and the great array of their substitued or modified derivatives. Nevertheless an increasing interest is attracted by polyaminopolyphosphonic and - phosphinic acids, as witnessed in a recent review on their coordination properties. Despite the scarce literature on a-aminoalkyl phosphinic acid, they represent a very useful class of organic compounds. The close similarity with $\alpha$-aminocarboxylic acids suggests them as potential isoteric substitutes of this ubiquitous moiety. Furthermore, alkylamino and bis

*Corresponding author

Tel : +82-51-200-7249, Fax : +82-51-200-7259

E-mail : dijung@daunet.donga.ac.kr

${ }^{\dagger} \mathrm{S}$. K. Choi equally contributed to this study. (alkylamino)phosphinic acids represent optimal structural scaffolds for the preparation of novel ligands with improved properties. In sharp contrast with carboxylic and phosphonic moieties, the bidentate phosphinic may be introduced as bridging group in linear or cyclic molecules, allowing the formation of a larger number of five-membered chelate rings, well known to provide high stability to the corresponding complexes [7,9,13-15].

In addition, the lower ionic charge relating to phosphonates helps to obtain easily neutral or almost neutral metal complexes, better tolerated in vivo applications in view of the lower osmolarity of their solutions $[1,3,6,8]$.

To the best of our knowledge, there are no reports involving the reaction of hypophosphorous acid with formaldehyde and primary amines.

Our interests in $\alpha$-aminoalkylphosphinic and bis( $\alpha$-aminoalkyl)phosphinic acids lies in their coordination ability towards metal ions, thereby providing useful structural motifs for the preparation of multi-sited ligands. We were particularly interested (i) in assessing the behavior of primary amino acids in the condition described above, and (ii) in searching a route to obtain mixed carboxylic phosphinic ligands. The ditopic nature of hypophosphorous acid (a formal $\mathrm{P}(\mathrm{O})(\mathrm{OH})^{-}$dinucleophile) and of the primary amino group (a formal $\mathrm{RN}\left(\mathrm{CH}_{2}{ }^{+}\right)_{2}$ dielectrophile), could give rise either 
<smiles>COP1(=O)CN(CC(=O)O)CP(=O)(O)CN1CC(=O)O</smiles><smiles>CC(=O)CN1CP(=O)(O)CN(CC(=O)O)CP(=O)(O)C1</smiles><smiles>[2H]OP1(=O)CN(C(CO)CC(=O)O)CP(=O)(O)C(C(=O)O)CN1C(=O)O</smiles><smiles>CCOC(=O)CN1CP(=O)(O)CN(CC(=O)OC)CP(=O)(O)C1</smiles><smiles>O=C(O)CCC(C(=O)O)N1CP(=O)(O)CN(C(CCC(=O)O)C(=O)O)CP(=O)(O)C1</smiles><smiles>CCOC(=O)CN1CP(=O)(O)CN(CC(=O)OCC)P(=O)(O)C1</smiles>

Fig 1. Structural diagram of 3,7-dihydroxy-3,7-dioxoperhydro1,5,3,7-diazadiphosphocine-1,5-dicarboxylic acids 1, 2, 3 and its derivatives $4,5,6$.

to linear polymeric or to cyclic oligomeric products [1].

As a part of a research program related to the synthetic study of pharmacologically interesting compounds and good chelating agents for transition metal ions, we report here the synthesis of an unusual medium-sized ring heterocyclic ligand with mixed carboxylic-amino-phosphonic donating groups (Fig. 1).

\section{Materials and Methods}

\section{Experimental Section}

Melting points were determined on an electrothermal capillary melting point apparatus and uncorrected. TLC was performed on glass plates coated with silicon oxide (silicagel $60 \mathrm{~F}_{254}$ ) and compounds were visualized using a uv lamp. ${ }^{1} \mathrm{H}$ and ${ }^{13} \mathrm{C}$ NMR spectra were obtained with Bruker AC $2000(200 \mathrm{MHz}$ ) and Varian Gemini (200 or $300 \mathrm{MHz}$ ) spectrometers. Mass spectra were measured with HP $5890 \mathrm{GC} /$ Mass (70 eV, EI). The organic solvents and chemicals were obtained from commercial products and purified by the appropriate methods before use.

\section{Materials}

Except where noted, all starting materials were purchased from Aldrich, Fluka, Fisher, Lancaster, or TCI chemical companies and used as received. The following known compounds were prepared by literature procedures [11]: ethanol, DMSO, hexane, chloroform, water, butanol, propanol, and methanol. Known compounds prepared by modified procedures have been included in the supplemental information:

\section{Synthesis}

3,7-Dihydroxy-3,7-dioxoperhydro-1,5,3,7-diazadiphos phocine-1,5-diacetic acid 1.

A mixture of glycine $(0.75 \mathrm{~g}, 0.01 \mathrm{~mol})$, hypophosphorous acid $(0.55 \mathrm{~mL}, 0.01 \mathrm{~mol})$, paraformaldehyde $(1.8 \mathrm{~g}, 0.02$ $\mathrm{mol})$, and $6 \mathrm{M} \mathrm{HCl}(10 \mathrm{~mL})$ was stirred for $30 \mathrm{~min}$. And then the clear solution was left standing 3 days. A white solid product $(0.26 \mathrm{~g}$, yield $8 \%$ ), was then collected by filteration, washed with a small amount of cold water, ethanol and dried in vacuo. Unreacted starting materials remained in solution.: $\mathrm{mp} 273-275^{\circ} \mathrm{C}$; IR $\left(v, \mathrm{KBr}, \mathrm{cm}^{-1}\right)$ $3445(\mathrm{OH}), 2999,1718(\mathrm{C}=\mathrm{O}), 1652 ;{ }^{1} \mathrm{H} \mathrm{NMR}\left(\mathrm{D}_{2} \mathrm{O}, \mathrm{pH} 10\right.$, $200 \mathrm{MHz}) \delta 3.87(\mathrm{~s}, 4 \mathrm{H}), 3.50(\mathrm{~d}, 8 \mathrm{H}, J=9.3 \mathrm{~Hz}) ;{ }^{13} \mathrm{C}$ NMR $\left(\mathrm{D}_{2} \mathrm{O}, \mathrm{pH} \mathrm{10}, 50 \mathrm{MHz}\right) \delta 178.5,59.2,55.6$; MS (MALDITOF), m/z 331 (Anal. caled for C 26.24; H, 5.50; N, 7.65; $\mathrm{P}, 16.92$ Found; $\mathrm{C}, 26.50 ; \mathrm{H}, 5.33 ; \mathrm{N}, 7.36 ; \mathrm{P}, 16.71$ ).

3,7-Dihydroxy-3,7-dioxoperhydro-1,5,3,7-diazadiphos phocine-1,5-di-(2-glutaric acid) 3.

A mixture of L-glutamic acid $(1.47 \mathrm{~g}, 0.01 \mathrm{~mol})$, hypophosphorous acid $(0.55 \mathrm{~mL}, 0.01 \mathrm{~mol})$, paraformaldehyde $(1.8 \mathrm{~g}, 0.02 \mathrm{~mol})$, and $6 \mathrm{M} \mathrm{HCl}(20 \mathrm{~mL})$ was stirred for 30 $\mathrm{min}$. And then the clear solution was left standing 3 days. In order to precipitate solid, the clear solution in refrigerator was kept for $24 \mathrm{hr}$. After filtering precipitated solid, it was washed by hexane and chloroform. A white solid product $(0.32 \mathrm{~g}$, yield $6.8 \%)$ was then collected: $\mathrm{mp}$ $304-306^{\circ} \mathrm{C}$; IR $\left(v, \mathrm{KBr}, \mathrm{cm}^{-1}\right) 3448(\mathrm{OH}), 2956,1731(\mathrm{C}=\mathrm{O})$, 1655; ${ }^{1} \mathrm{H}$ NMR $\left(\mathrm{D}_{2} \mathrm{O}, \mathrm{pH} 10,200 \mathrm{MHz}\right) \delta 4.27(\mathrm{~s}, 2 \mathrm{H}), 3.87(\mathrm{~s}$, $4 \mathrm{H}), 3.50(\mathrm{~d}, 8 \mathrm{H}, J=9.3 \mathrm{~Hz}), 2.42(\mathrm{t}, 4 \mathrm{H}, J=13.8 \mathrm{~Hz}), 2.08(\mathrm{~m}$, $4 \mathrm{H}) ;{ }^{13} \mathrm{C}$ NMR $\left(\mathrm{D}_{2} \mathrm{O}, \mathrm{pH} 10,50 \mathrm{MHz}\right) \delta 173.0,172.6,170.4$, $169.7,52.3,51.5,48.9,25.8$.

\section{3,7-Dihydroxy-3,7-dioxoperhydro-1,5,3,7-diazadiphos} phocine-1,5-diacetic acid methyl ester 4.

A mixture of synthesized 1,5-diacetic acid $1(0.99 \mathrm{~g}, 3 \times$ $\left.10^{-3} \mathrm{~mol}\right)$ with mathanol $(15 \mathrm{~mL})$ as solvent and reagent was stirred for $30 \mathrm{~min}$. After the reaction mixture was refluxed under $\mathrm{N}_{2}$ for $24 \mathrm{hr}$ and dried. The organic layer was filtered and concentrated. A light green solid product $(0.80 \mathrm{~g}$, yield $74.5 \%)$ then collected: $\mathrm{mp} 273-275^{\circ} \mathrm{C}$; IR $\left(v, \mathrm{KBr}, \mathrm{cm}^{-1}\right)$ 3383, 1749 (C=O); ${ }^{1} \mathrm{H}$ NMR $\left(\mathrm{D}_{2} \mathrm{O}, \mathrm{pH} 10,200 \mathrm{MHz}\right) \delta 4.12$ $(\mathrm{s}, 4 \mathrm{H}), 3.57(\mathrm{~s}, 6 \mathrm{H}), 3.42(\mathrm{~d}, 8 \mathrm{H}, J=9.34 \mathrm{~Hz}) ;{ }^{13} \mathrm{C}$ NMR $\left(\mathrm{D}_{2} \mathrm{O}\right.$,

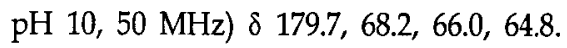

\section{3,7-Dihydroxy-3,7-dioxoperhydro-1,5,3,7-diazadiphos} phocine-1,5-diacetic acid ethyl ester 5.

A mixture of synthesized 1,5-diacetic acid $1(0.99 \mathrm{~g}, 3 \times$ 
$\left.10^{-3} \mathrm{~mol}\right)$ with ethanol $(15 \mathrm{~mL})$ as solvent and reagent was stirred for $30 \mathrm{~min}$. After the reaction mixture was refluxed under $\mathrm{N}_{2}$ for $5 \mathrm{hr}$, the organic layer was filtered, concentrated, and dried. A light yellow solid product $(0.82 \mathrm{~g}$, yield $71 \%)$ was then collected: $m p 312-314^{\circ} \mathrm{C}$; $\mathrm{IR}(\mathrm{v}, \mathrm{KBr}$, $\left.\mathrm{cm}^{-1}\right)$ 3385, 2930, 1750(C=O); ${ }^{1} \mathrm{H}$ NMR $\left(\mathrm{D}_{2} \mathrm{O}, \mathrm{pH} 10,200\right.$ $\mathrm{MHz}) \delta 4.10(\mathrm{~s}, 4 \mathrm{H}), 4.01(\mathrm{~d}, 6 \mathrm{H}, J=7.1 \mathrm{~Hz}), 3.46(\mathrm{~d}, 8 \mathrm{H}, J=7.4$ $\mathrm{Hz}), 1.00(\mathrm{t}, 6 \mathrm{H}, J=14.2 \mathrm{~Hz}) ;{ }^{13} \mathrm{C}$ NMR $\left(\mathrm{D}_{2} \mathrm{O}, \mathrm{pH} 10,50\right.$ $\mathrm{MHz}) \delta$ 179.1, 74.8, 67.9, 68.4, 66.1, 24.6.

\section{3,7-Dihydroxy-3,7-dioxoperhydro-1,5,3,7-diazadiphos} phocine-1,5-diacetic acid propyl ester 6 .

A mixture of synthesized 1,5-diacetic acid $1(0.99 \mathrm{~g}$, $\left.3 \times 10^{-3} \mathrm{~mol}\right)$ with propanol $(15 \mathrm{~mL})$ as solvent and reagent was stirred for $30 \mathrm{~min}$. After the reaction mixture was refluxed under $\mathrm{N}_{2}$ for $5 \mathrm{hr}$, the organic layer was filtered, concentrated, and dried. A light yellow solid product $(0.86$ $\mathrm{g}$, yield $69.4 \%)$ was then collected: $\mathrm{mp} 335-337^{\circ} \mathrm{C}$; IR $(\mathrm{v}$, $\left.\mathrm{KBr}, \mathrm{cm}^{-1}\right) 3384,2932,1748(\mathrm{C}=\mathrm{O}) ;{ }^{1} \mathrm{H}$ NMR $\left(\mathrm{D}_{2} \mathrm{O}, \mathrm{pH} 10\right.$, $200 \mathrm{MHz}) \delta 4.05$ (s, 4H), 3.86(d, $4 \mathrm{H}, J=6.7 \mathrm{~Hz}), 3.36(\mathrm{~d}, 8 \mathrm{H}$, $J=9.3 \mathrm{~Hz}), 1.35(\mathrm{dd}, 4 \mathrm{H}, J=7.1 \mathrm{~Hz}), 0.59(\mathrm{t} .6 \mathrm{H}, J=14.8 \mathrm{~Hz}) ;{ }^{13} \mathrm{C}$ NMR $\left(\mathrm{D}_{2} \mathrm{O}, \mathrm{pH} 10,50 \mathrm{MHz}\right) \delta 179.7,80.0,68.1,66.0,32.5$, 20.8 .

\section{Results and Discussion}

As a part of research program related to the synthetic study of pharmacologically interesting compounds and good chelating agents for transition metal ions, we report here the synthesis and esterification of an unusual medium sized ring heterocyclic ligand with mixed carboxylicaminophosphonic donating groups. In order to synthesize 3,7-dihydroxy-3,7-dioxoperhydro-1,5,3,7-diazadiphosphocine1,5-diacetic acid 1 , the reaction was then performed, adopting glycine as a model amino acid in aq. $\mathrm{HCl}$ (Scheme 1).

The strongly acidic medium is required to promote the second reaction of $\mathrm{H}_{3} \mathrm{PO}_{2}$ and to avoid the side reactions of the iminium ion such as the reduction by means of formaldehyde to $\mathrm{N}$-methyl derivatives.

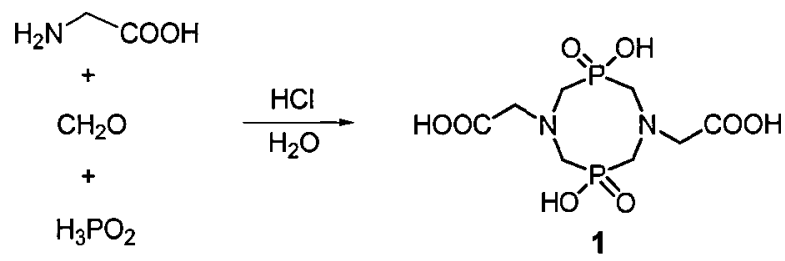

Scheme 1
The reaction was found to be highly dependant on the experimental conditions employed. High concentrations of the reactant, heat and very long reaction times led to extensive formation of polymeric products; conversely, low acidity $(\mathrm{pH}>1)$ and low reactant concentrations gave rise to complex mixtures. A clean reaction was effected dissolving glycine and $\mathrm{H}_{3} \mathrm{PO}_{2}$ in $6 \mathrm{M} \mathrm{HCl}$ to obtain a $1.0 \mathrm{M}$ solution in both reagents and adding paraformaldehyde in slight excess ( 3 equiv.) in one portion. Complete dissolution was achieved by stirring for $30 \mathrm{~min}$ and then the clear solution was left standing for $30 \mathrm{~min}$ and then the clear solution was left standing for 3 days. A white solid product was then collected by filtration, washed with a small amount of cold water, ethanol and dried in vacuo.

NMR analysis of the product showed a highly symmetrical molecule, (two signals in ${ }^{1} \mathrm{H}$ NMR and three signals in the ${ }^{13} \mathrm{C}$ NMR) with a molecular weight of 330 a.m.u., characterized as 3,7-dihydroxy-3,7-dioxoperhydro-1,5,3,7-diazadiphosphocine-1,5-diacetic acid 1. This heterocyclic ligand results from the assembly of two molecules of glycine, two molecules of $\mathrm{H}_{3} \mathrm{PO}_{2}$ and four molecules of formaldehyde; its striking feature is that each atom of this eight-membered ring is originated from eight single different molecules, representing a formal ' $1+1+1+1+1+1+1+1$ ' cyclocondensation. The yield is satisfactory despite the number of elemental steps involved in the overall transformation and of the ring size, usually unfavorable for entropic reasons. And also reactions were performed by treatment of aspartic acid or glutamic acid in behalf of glycine in aq $\mathrm{HCl}($ Scheme 2).

The reaction of glutamic acid with paraformaldehyde and $\mathrm{H}_{3} \mathrm{PO}_{2}$ gave 3,7-dihydroxy-3,7-dioxo-perhydro-1,5,3,7diazadiphosphocine-1,5-di-(2-glutaric acid) 3. MS showed a protonated molecular ion at $\mathrm{m} / \mathrm{z} 475$ corresponding to the molecular formular $\mathrm{C}_{8} \mathrm{H}_{16} \mathrm{~N}_{2} \mathrm{O}_{8} \mathrm{P}_{2}$. ${ }^{1} \mathrm{H}-\mathrm{NMR}$ showed a singlet at $\delta 4.27$ for two protons, a singlet at $\delta 3.87$ for four proton, a doublet at $\delta 3.50$ for eight protons, a triplet at $\delta$ 2.42 for four protons, and a multiplet at $\delta 2.08$ for four protons. From these observation this product was proposed to have the structure of carboxylic acid 3 .

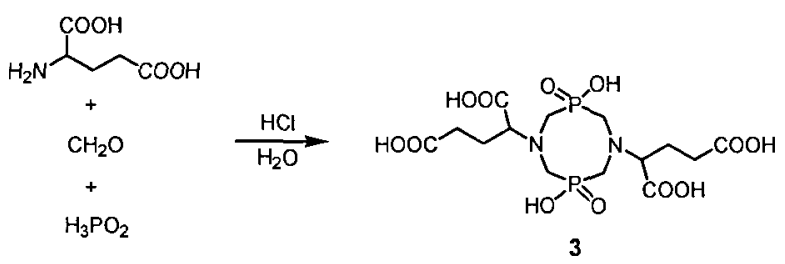

Scheme 2 
However, the reaction of aspartic acid with paraformaldehyde and $\mathrm{H}_{3} \mathrm{PO}_{2}$ did not give the expected product, 2-[5-(1,2-dicarboxyethyl)-3,7-dihydroxy-3,7-dioxo-315.715$[1,5,3,7]$-diazadiphosphocan-1-yl]-succinic acid 2. We will try synthesis of carboxylic acids by treatment of various amino acid.

Esterification of synthesized compound 1 by methanol, ethanol and propanol gave acid ester compound 4, 5, 6. In the case of acid ester $4,{ }^{1} \mathrm{H}$ NMR showed a singlet at $\delta 4.12$ for four protons, a singlet $\delta 3.57$ for six protons and a doublet at $\delta 3.42$ for eight protons $(J=9.4 \mathrm{~Hz})$. And MS showed a protonated molecular ion at $\mathrm{m} / \mathrm{z} 358$ corresponding to the molecular formular $\mathrm{C}_{10} \mathrm{H}_{20} \mathrm{~N}_{2} \mathrm{O}_{8} \mathrm{P}_{2}$. From these observations, this product was proposed to have the structure of 3,7-dihycholy-3,7-dioxoperhydro-1,5,3,7-diazadiphosphocine-1,5-diacetic acid methyl ester 4 . Structures of acid ester 5 and acid ester 6 was suggested by the similar manner as acid ester 4.

The relative position of the functional groups is particulary interesting in view of the possible application of carboxylic acid 1 as ligand for metal ions. The $\mathrm{N}-\mathrm{CH}_{2} \mathrm{COOH}$ and $\mathrm{N}-\mathrm{CH}_{2}-\mathrm{P}(\mathrm{O}) \mathrm{OH}-\mathrm{CH}_{2}-\mathrm{N}$ moieties are known to chelate efficiently through formation of five-membered rings with the metal atom. Furthermore, the latter is embraced by the six donor atoms in a nearly ideal octahedral arrangement, highly advantageous for the complexation of the hexacoordinated transition metal ions. Hence we will start a preliminary investigation on the binding properties of carboxylic acid 1 towards $\mathrm{Mn}^{2+}$ and $\mathrm{Gd}^{3+}$, two paramagnetic ions of choice in the design of contrast agents for MRI, with different chemical behaviors and whose magnetic features help in the investigation of the solution structures of the corresponding adducts.

\section{Acknowledgment}

The work was supported by the grant from Dong-A university(2006).

\section{References}

1. Aime, S., C. Cavallotti, E. Gianolio, G. B. Giovenzana, G. Palmisano and M. Sist. 2002. One-step synthesis of a new eight-membered cyclic ligand from glycine, formaldehyde and hypophosphorous acid. Tetrahedron Lett. 43, 83878389.

2. Akiyoshi, K., T. Nishikawa, S. Shichibe and J. Sunamoto.
1995. Stabilization of Insulin upon Supramolecular Complexation with Hydrophobized Polysaccharide Nanoparticle. Chem. Lett. 8, 707-708.

3. Albrecht, S., Z. Claus, G. Cindy, J. Manuela, M. Franziska and J. Tobias. 2004. Iron oxide particles for molecular magnetic resonance imaging cause transient oxidative stress in rat macrophages. F. Radio. Bio. Med. 36, 976-984.

4. Arnold, P., J. Ward and D. Wilson. 2003. Superparamagnetic iron oxide (SPIO) enhancement in the cirrhotic liver: a comparison of two doses of ferumoxides in patients with advanced disease. Mag. Res. Imag. 21, 695-700.

5. Bodern, N. R., J. Bushby, S. Clarcksonm S. D, Evans, P. F. Knowles and A. Marsh. 1997. The design and synthesis of simple molecular tethers for binding biomembranes to a gold surface. Tetrahedron 53, 10939-10952.

6. Ladd, D. L., R. Hollister, X. Peng, D. Wei, G. Wu, D. Delecki R, A. Snow, J. L. Toner, K. Kellar, J. Eck, V. C. Desai, G. Raymond, L. B. Kinter, T. S Desser and D. L Rubin. 1999. Polymeric Gadolinium Chelate Magnetic Resonance Imaging Contrast Agents: Design, Synthesis and Properties. Bioconjugate Chem. 10, 361-370.

7. Lattuada, L. and Lux, G. 2003. Synthesis of Gd-DTPAcholesterol: a new lipophilic gadolinium complex as a potential MRI contrast agent. Tetrahedron Lett. 44, 3893-3895.

8. Lauffer, R. B. and T. J. Brady. 1985. Preparation and water relaxation properties of proteins labeled with paramagnetic metal chelates. Mag. Res. Imag. 3, 11-16.

9. Reichert, D. E., S. J. Lewis and C. J. 1999. Anderson. Metal complexes as diagnostic tools. Coord. Chem. Rev. 184, 3-66.

10. Schmiedl, U., M. Ogan, H. Paajanen, M. Marotti, L. E. Crooks, A. C. Brito and R. C. Brasch. 1987. Albumin labeled with Gd-DTPA as an intravascular, blood pool-enhancing agent for MR imaging: biodistribution and imaging studies. Radiology 162, 205-210.

11. Tatchell, A. R., P. W. G. Smith, V. Rogers, A. J. Hannaford and B. S. Furniss. 1978. Vogel's Textbook of Practical Organic Chemistry. pp. 264-319, 4th eds., The Chaucer Press, London.

12. Tatsuhirom, Y., I. Kenjiro, O. Keiji, A. Kohtaro, U. Toyokazu, H. Fuminori and M. Masaharu. 2004. In vivo MR detection of vascular endothelial injury using a new class of MRI contrast agent. Bioorg. Med. Chem. Lett. 14, 2787-2790.

13. Thunus, L. and R. Lejeune. 1999. Overview of transition metal and lanthanide complexes as diagnostic tools. Coord. Chem. Rev. 184, 125-155.

14. Tournier, H., R. Hyacinthe and M. Schneider. 2002. Gadolinium-Containing Mixed Micelle Formulations: A New Class of Blood Pool MRI/MRA Contrast Agents. Acad. Radiol. 9, S20-S28.

15. Vu, H., H. T. Schmaltz and K. Jayaraman. 1994. Synthesis and Properties of Cholesteryl-Modified Triple-Helix Forming Oligonucleotides Containing a Triglycyl Linker. Bioconjungate Chem. 5, 666-668. 


\section{초록 : 1,5,3,7-Diazadiphosphocine-1,5-Dicarboxylic Acids의 합성과 반응}

정대일 $^{*} \cdot$ 조승환 ${ }^{1} \cdot$ 송주현 $\cdot$ 이도훈 $\cdot$ 이용균 $\cdot$ 박유미 · 최순규 ${ }^{\dagger}$ 한정태 ${ }^{2}$

(동아대학교 화학과, ${ }^{1}$ 한미제약, ${ }^{2}$ 영동대학교 뷰티케어과)

본 연구는 MRI 조영제나 새로운 생리활성 물질을 개발키 위해 paraformaldehyde와 hypophosphorous acid를 아미노산인 glycine 혹은 glutamic acid와 함께 반응시켜 3,7-dihydroxy-3,7-dioxoperhydro-1,5,3,7-diazadiphosphocine-1,5-diacetic acid 1와 3,7-dihydroxy-3,7-dioxoperhydro-1,5,3,7-diazadiphos-phocine-1,5-di-(2-glutaric acid) 3을 합성하였다. 그러나 aspartic acid에 의한 2-[5-(1,2-dicarboxy-ethyl)-3,7-dihydroxy-3,7-dioxo-315.715-[1,5,3,7] diazadiphosphocan-1-yl]-succinic acid 2는 얻지 못했다. 합성된 3,7-dihydroxy-3,7-dioxoperhydro-1,5,3,7-diazadiphosphocine-1,5-diacetic acid 1을 산 촉매에 의한 에스테르화반응시켜 화합물 3,7-dihydroxy-3,7-dioxoperhydro-1,5,3,7-diazadiphosphocine-1,5-diacetic acid methyl ester 4, 3,7-dihydroxy-3,7-dioxoperhydro-1,5,3,7-diazadiphosphocine-1,5-diacetic acid ethyl ester 5, 그리고 3,7-dihydroxy-3,7-dioxoperhydro-1,5,3,7-diazadiphosphocine1,5 -diacetic acid propyl ester 6 을 합성하였다. 계속해서 다양한 반응을 통해 새로운 화합물을 합성할 것이며 생 리활성검색도 실시할 예정이다. 